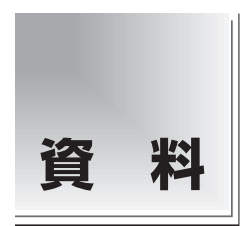

論文受付

2014 年 6 月 5 日

論文受理

2014年12月14日

Code No. 190

\section{診療放射線技師の業務に関連したインシデントレポート 一過去 10 年間分の解析結果一}

\author{
橋田昌弘 ${ }^{1,2}$ 白石順二 ${ }^{3}$
}

1 熊本大学医学部附属病院医療技術部

2 熊本大学大学院保健学教育部

3 熊本大学大学院生命科学研究部

\section{諸 言}

医療に扔いて，患者の安全を確保し安心を与えるこ とは，すべての診療において最も基本的な事項である ことはいうまでもない。しかし，以前は，医療事故は 当事者個人の問題や責任と処理され，医療事故の再発 が繰り返されてきた. 1999 年の患者間違い手術の医 療事故の反省から, 日本では医療安全に関して国(厚
生労働省)や医療施設(病院，診療所等)が本格的に取 り組み始めた。 1999 年に米国 Institute of Medicine (IOM) から「To Err is Human 」1) が報告され，「人は誰 でも間違える」ことを前提とし，危険な事象が起こっ た(または起こりそうになった)場合でも，当事者を責 めるのではなく，その事象の起こった環境，組織等を チェックし人間工学的に改善し再発防止につなげるこ

\title{
Incident Reports Related to Tasks Performed by Radiological Technologists: An Analysis of Ten Years of Incident Reports
}

\author{
Masahiro Hashida ${ }^{1,2}$ and Junji Shiraishi ${ }^{3}$ \\ ${ }^{1}$ Department of Radiology, Hospital Division of Medical Technology, Kumamoto University Hospital \\ ${ }^{2}$ Graduate School of Health Sciences, Kumamoto University \\ ${ }^{3}$ Faculty of Life Sciences, Kumamoto University
}

Received June 5, 2014; Revision accepted December 14, 2014

Code No. 190

\section{Summary}

In the past 10 years at our university hospital, 202 incident reports related to tasks performed by radiological technologists were posted. In order to investigate the causes and trends of these incidents, we classified the incident reports into four groups based on the event content, level of harm caused to the patient, years of experience of the concerned radiological technologist, and relevant departmental section. In the event content group, 'a malfunctioning device' was the most common event (26.2\%), whereas the other events were 'wrong examination procedure or therapy' (15.3\%), 'patient fall' (10.9\%), 'procedure-patient mismatch' (8.4\%), 'accidental removal of patients' tubes or other intravenous devices' (7.9\%), and 'bringing metallic material into the magnetic resonance imaging (MRI) room' (7.4\%). In the level of harm caused to the patient group, level one events occurred frequently. Radiological technologists with 6-16 years of experience reported incidents most frequently. With regard to the relevant departmental section where the incidents occurred, departments with the highest number of reports were ranked as follows in descending order: general X-ray examination section, MRI section, radiation therapy section, nuclear medicine (NM) section, computed tomography (CT) section, angiography section, and fluoroscopy section. The following events in each corresponding section require careful monitoring: patient fall in the general X-ray examination section and NM section, bringing metallic material into the MRI room, malfunctioning devices in the radiation therapy section, accidental removal of the patient's tubes in the CT section, incorrect handling of the automatic contrast medium injector in the angiography section, and damage of device or article in the fluoroscopy section.

Key words: incident report, patient safety, risk management, radiological technologist, radiology

*Proceeding author 
とが重要とされた。その取り組みの一つとして, イン シデント(ヒヤリ・ハット)レポートが各医療施設で実 施され，多くの事例が集約されてきた。本院でも， 2001 年よりインシデントレポートシステムが動き始 め, 現在では年間 1500 件以上の事象が報告されてい る。しかし一方では，インシデントレポートを報告す ることだけに重点が置かれ，安全対策がマンネリ化し ている実態があり，インシデントレポートシステムを 安全対策に十分生かすような提言もある ${ }^{2 \sim 4)}$.

放射線診療部門における医療安全の取り組みに関し て, 日本放射線技術学会(本学会)では, 2004 年に熊谷 らがアンケートによる事例収集の解析結果を報告して いる ${ }^{5-7)}$. 海外においては, 2008 年に, Kruskal らが, 放射線部診療部門での有害事象を分析し具体的なリ又 クマネジメントを提唱し ${ }^{8)}$, 更に, 2009 年には天内(編 者）らによって, 放射線診療部門の医療安全に関する テキストが発刊され，各部門での具体的な事例と注意 点が報告されている9 . また, 医療安全に対する取り 組みは関連学会においても同様に行われ，2002 年は日 本医学放射線学会から事故防止のための指針 ${ }^{10)}, 2007$ 年には 3 団体 (日本放射線技術学会, 日本放射線技師 会, 日本画像医療システム工業会) から安全の質管理 指針 ${ }^{11}$ が出され，安全の質管理のための具体的なマ ニュアル ${ }^{12)}$ も提示されている.

近年, 本学会では, 安全管理に関する報告が多くな り, 2012 年に土井らは経験年数を ${ }^{13)}, 2013$ 年に安田ら は危険予知トレーニングを ${ }^{14)}$ ，そして，2014 年には西 村らがヒューマンエラーについて ${ }^{15)}$ ，それぞれテーマ として取り上げ安全対策を提唱している。また，モダ リティ別の安全管理として, 土井らは具体的に magnetic resonance imaging (MRI) 装置の安全管理に関す るアンケート調査から実態を報告し ${ }^{16)}$ ，山谷らは特に MRI 検査での大型強磁性体吸引事故を分析している ${ }^{17}$.

医療での安全を担保するための方策を検討するうえ では，実際の現場で発生したインシデントレポートは 重要な情報源である。しかし, 熊谷らのアンケート集 計報告から 10 年経過し, 近年に扔いては, 放射線診療 部門で発生した事例に関する報告はわれわれの知る限 りみられない，更に，熊谷らの報告はアンケートによ る回答をまとめたもので, 実際の現場での事例の詳細 は判断できない，本研究は，本院で実際に発生した放 射線診療に関する過去 10 年間のインシデントレポー 卜を分析し, 放射線診療や各部門の安全面での特徵を 検討し, 放射線診療で安全を担保できるための情報を 提供することを目的とする。

\section{1. 方 法}

2004 年 4 月から 2014 年 3 月までの, 本院で報告の あった放射線診療に関係するインシデントレポートの 中で, 診療放射線技師 (技師) が当事者である場合や直 接的，間接的に技師が関与したケース 202 例を分析の 対象とした，造影剂等の薬剂の漏れや造影剂による副 作用の事例は除いた。これは, 2010 年 10 月からイン シデントレポート投稿システムが更新され，それ以前 のデー夕は参照できず紙べースでの記録となり, 上記 の事例の抽出が困難となったためである。 また, 本研 究のインシデントレポートの分析は, 本学大学院生命 科学研究部等疫学・一般研究倫理委員会の承認を受け ている(倫理第 808 号).

インシデントレポートを事象の内容別, レベル別, 報告者の経験年数別, 発生した部門別に分類し, 分析 した。事象の内容別では, 前期 (2004 年〜2008 年) と 後期 (2009 年〜2013 年)の 2 期に分け検討した。 また, レベルと報告者の経験年数に関しては, 平成 23 年度 と平成 24 年度の病院全体のレポート(総数：3588 件, 放射線診療からのレポートを含む)からデー夕を抽出 し, 放射線診療部門と病院全体を比較した。

インシデントのレベル分類について, 本院は国立大 学附属病院医療安全管理協議会のインシデント影響度 分類を採用しているため，下記のレベル内容とした。 レベル 0:エラーや医薬品, 医療機器の不具合がみら れたが，患者には実施されなかった。レベル1：患者 への実害はなかった(何らかの影響を与えた可能性は 否定できない)。レベル 2 : 処置や治療は行わなかった (患者観察の強化, バイタルサインの軽度変化, 安全確 認のための検査などの必要性は生じた)。レベル $3 \mathrm{a}$ ： 簡単な処置や治療を要した(消毒, 湿布, 皮膚の縫合, 鎮痛剤の投与など)。なお, レベル $3 \mathrm{~b}$ 以上は本院では 医療事故として報告するため, 今回の分析からは除 いた。

本院は, 病床 : 850 床, 診療科数: 28 , 外来患者数 (1 日平均) : 約 1,300 人, 画像診断㧍よび治療装置(移動 型を含む)：61 台，技師数：43人である.

\section{2. 結 果}

インシデントの内容別件数を Fig. 1 に示す. インシ デントの内容を下記の項目に分類し, 件数の多い順に 示す.

(1)装置の故障 : $26.2 \%$ (装置の故障による検査(治療)の 中止や延期), (2)検査 (治療)の内容に関すること： 15.3\%(部位や左右の間違い, 検査の漏孔や順番間違い 等)，(3)転倒，転落，しりもち：10.9\%，(4)患者に関す 


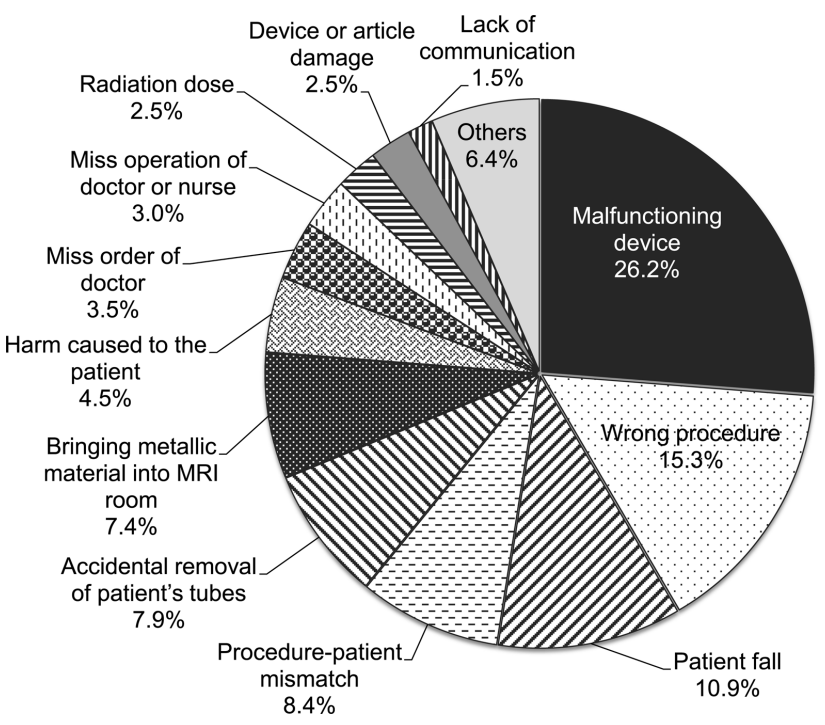

Fig. 1 Contents of incident events $(n=202)$.

ること： 8.4\%(患者誤認, 氏名登録間違い, フィルム入 れ間違い等), (5)点滴ルート等の引き抜け等: $7.9 \%$, (6) MRI 検査室への金属類の持込み：7.4\%，(7)患者の受 傷： $4.5 \%$ (転倒や転落でない場合), 8オーダミス： 3.5\% (医師のオーダ間違い), 9技師以外のスタッフの 操作ミス: $3.0 \%$, (10)線量に関すること : $2.5 \%$ (過大, 過 小照射, 患者被ばく線量等), (11)物損: $2.5 \%$, (12)患者情 報の伝達に関すること：1.5\%（感染情報の伝達不備 等)，(13)その他： $6.4 \%$ 。また，1番件数の多かった装置 の故障では, 装置の使用年数は, $1 \sim 3$ 年 (16 件), $4 \sim 6$ 年 (15 件), $7 \sim 9$ 年 (13 件), 10 年以上 (3 件)であった. 内容別件数で, 前期 (2004 年〜2008 年) を Fig. 2(a) に, 後期 (2009 年〜2013 年)を Fig. 2(b)に示す。レポート 数は，前期が 76 件，後期が 126 件であり，共に「装置 の故障」が一番多かった。

レベル別件数を Fig. 3 に示す．レベル分類では，レ ベル 1 が一番多く(58.4\%), ついでレベル 2(19.3\%), レベル 0(15.3\%)，レベル 3a(6.9\%)の順となった。 レ ベル $3 \mathrm{a}$ (14 件)では部門では撮影部門 (6 件), 内容では 患者受傷 (転倒等がないケース) (5 件) と転倒等 (4 件) が多かった。レベル 2 (39 件)では部門では撮影部門 (14 件), 内容では転倒等 (13 件) と点滴ルート等の引 き抜け (7 件)が多かった。レベル 1 では (118 件)では 装置故障 (42 件) と検査内容に関すること (24 件) が多 かった。レベル 0 (31 件)では MRI 部門 (10 件)が多 く，その中でも金属持込み(7 件)が多かった，病院全 体のレベル分類では，レベル 2 が一番多く(41.1\%)， ついでレベル $1(37.3 \%)$ ，レベル $3 \mathrm{a}(13.0 \%) ，$ レベル 0 (8.7\%)の順であった.

Fig. 4 にレポートの報告者の経験年数別件数を示
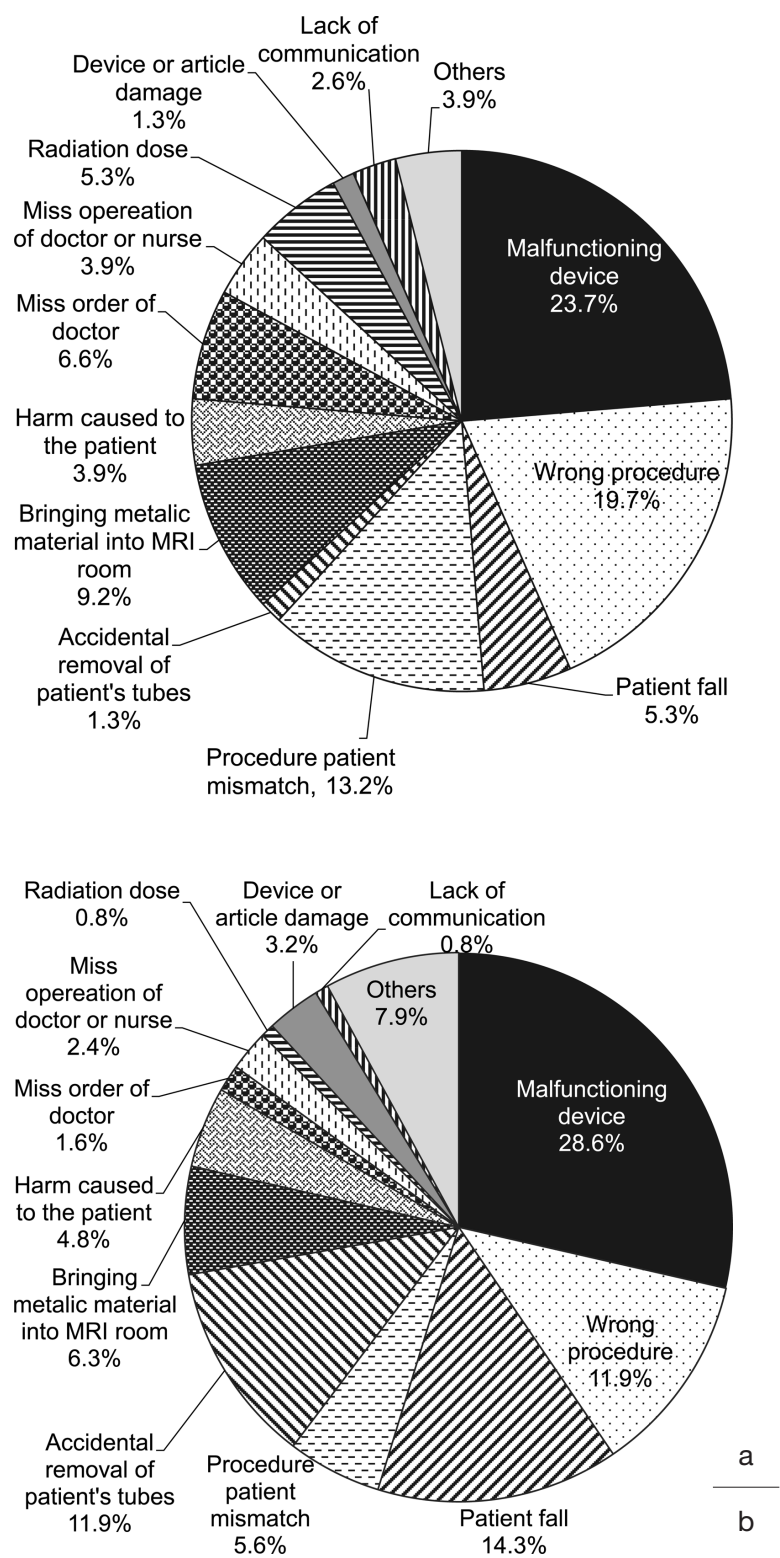

Fig. 2 Contents of incident events: the past 5 years.

We divided the term of analysis into two terms, the first term (2004-2008 years) and the second term (2009-2013 years).

(a): The first term (2004-2008 years) $(n=76)$.

(b): The second term (2009-2013 years) $(n=126)$.

す．技師が当事者だったケースで，装置故障を除いた 91 件の内訳である。 6 年以上 16 年未満が一番多く (31.9\%), ついで 16 年以上 $(23.1 \%), 3$ 年以上 6 年未 満 $(16.5 \%), 1$ 年末満と 1 年以上 3 年未満が同数 (14.3\%)の順となった。病院全体では, 1 年以上〜 3 年 未満が一番多く(34.7\%), ついで 1 年未満( $32.7 \%), 3$ 年以上 6 年未満 $(21.1 \%), 6$ 年以上 16 年未満 (10.3 $\%), 16$ 年以上 (1.2\%)の順であった。

Fig. 5 に部門別件数を示す.X 線撮影部門が一番多 く(23.8\%), ついで MRI 部門 (19.8\%), 放射線治療部 門 (18.3\%), 核医学部門 (12.4\%), Computed tomog- 


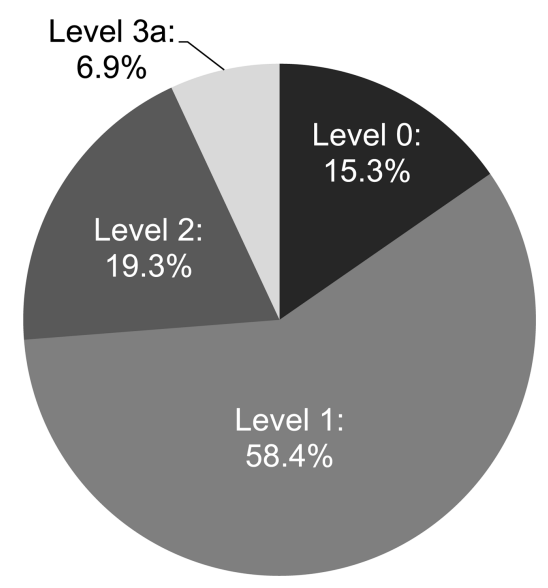

Fig. 3 Ratio of the level of harm caused to the patient $(n=202)$. Level 0: an error occurred but did not reach the patient, Level 1: an error occurred, reached the patient but did not harm the patient,

Level 2: an error occurred, reached the patient and required monitoring to confirm no harm, Level 3a: an error occurred, likely caused temporary harm and required intervention.

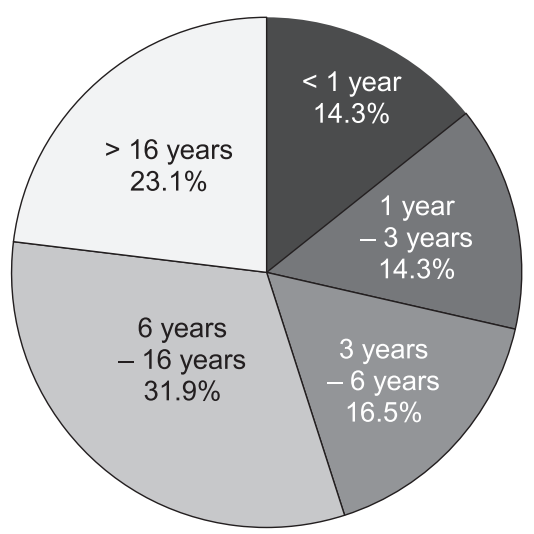

Fig. 4 Ratio of the year of experience of the concerned radiological technologist $(n=91)$.

$\operatorname{raphy}(\mathrm{CT})$ 部門 $(8.9 \%)$ ，透視部門と血管造影部門が同 数 (5.9\%), 病棟・手術室 $(5.0 \%)$ の順であった。また, Table に, 各部門での上位 3 項目のインシデントの内 容を示す. 数字は件数で, 括弧内は部門内でのレポー 卜総数に占める割合 $(\%)$ である.

\section{3. 考 察}

\section{3-1 インシデントの内容の分析}

インシデントの内容別では, 装置の故障を要因とす るものが一番多く(Fig. 1), この中では, 放射線治療部 門と核医学部門からの報告が $68.5 \%$ を占める。また, 別の見方をすれば, 治療部門におけるインシデント全 体の $62.2 \%$, 核医学部門の $56.0 \%$ が装置故障の報告で

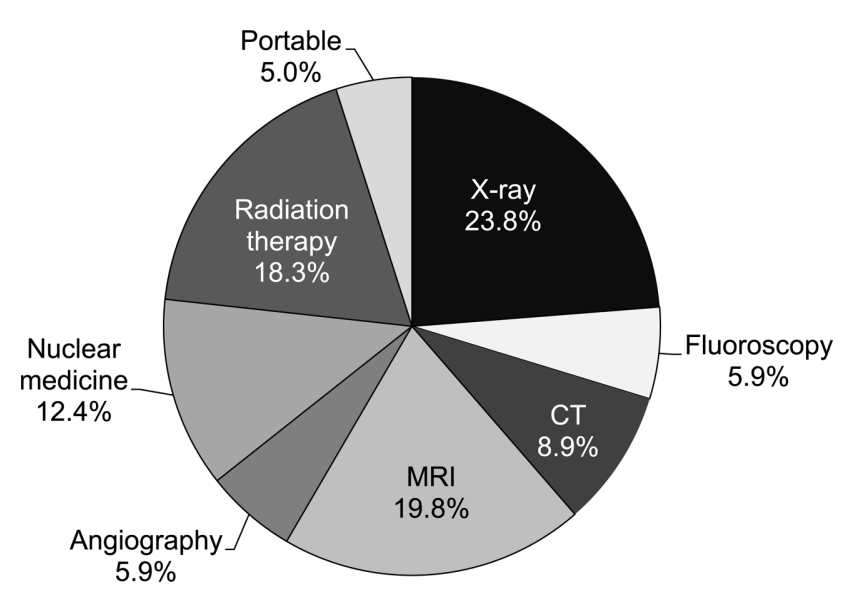

Fig. 5 Ratio of the relevant departmental section $(n=202)$.

あった(Table). 本中央放射線部の取り決めとして, 装置の故障によって当日検査 (治療)が中止や後日延期 になった場合には，患者に影響を及ぼす可能性がある として, 病院のインシデントレポートシステムへ入力 することになっている，そして，装置の故障があって も，極端な遅れが発生せずに当日中に予定されていた 検査(治療)がすべて実施された場合には，部内報告と している。しかし, 通常の放射線治療では, 治療開始 から終了まで, 装置の特性や患者不安を考慮して, 治 療装置(リニアック)を途中で変更しないようにしてい る。そのため,リニアック装置の故障は当日の治療中 止に結びつき，それが，インシデントレポートが多く なった原因である。また，核医学部門の故障報告で は, positron emission tomography (PET) 装置の故障 が全体の $86 \%$ を占めていた。本院では PET 装置を 1 台しか保有していないために, 装置の故障によって検 査が中止となる場合が多く，そのためインシデントレ ポートが多くなったと考える。また, 心臓カテーテル 検査や interventional radiology (IVR) 中の装置の故障 は 7 件(停電の 1 件を含む) 発生したが, 適切な対応に よって医療事故に発展しなかった。患者の使用が限定 される装置, 1 台のみ保有の装置, 患者の危険性が大 きい検査・治療の装置では, 日頃からの定期点検や始 業・終業点検がより重要となる.

前期 (2004 年〜2008 年) と後期 (2009 年〜2013 年)を 比較すると, 前期が 76 件, 後期が 126 件と偏りがあっ た。これは, 2001 年からインシデントレポートシステ ムが運用開始されたものの, 前期の期間では全スタッ フにシステムの意義や重要性が周知(認識)されず，イ ンシデントが発生しても報告されない場合があり件数 が少なかったと推察する。また，人為的でない装置の 故障は約四分の一の割合で発生しており, 前述したよ 
Table The contents of incident events occurred frequently at most, second, and third in each departmental section

\begin{tabular}{|c|c|c|c|c|}
\hline $\begin{array}{l}\text { Departmental } \\
\text { section }\end{array}$ & X-ray & Fluoroscopy & CT & MRI \\
\hline \multirow[t]{2}{*}{ Most frequency } & Patient fall & Device damage & $\begin{array}{l}\text { Accidental removal } \\
\text { of patient's tubes }\end{array}$ & $\begin{array}{l}\text { Bringing metallic } \\
\text { material into MRI }\end{array}$ \\
\hline & $14(29.2 \%)$ & $2(16.0 \%)$ & $5(27.8 \%)$ & $15(37.5 \%)$ \\
\hline \multirow[t]{2}{*}{ Second frequency } & $\begin{array}{l}\text { Procedure-patient } \\
\text { mismatch }\end{array}$ & $\begin{array}{l}\text { Miss operation of } \\
\text { doctor or nurse }\end{array}$ & Wrong procedure & Wrong procedure \\
\hline & $9(18.8 \%)$ & $2(26.7 \%)$ & $5(27.8 \%)$ & $10(25.0 \%)$ \\
\hline \multirow[t]{2}{*}{ Third frequency } & Wrong procedure & $\begin{array}{l}\text { Procedure-patient } \\
\text { mismatch }\end{array}$ & $\begin{array}{l}\text { Malfunctioning } \\
\text { Device }\end{array}$ & $\begin{array}{l}\text { Accidental removal } \\
\text { of patient's tubes }\end{array}$ \\
\hline & $8(16.7 \%)$ & $1(18.3 \%)$ & $3(16.4 \%)$ & $5(12.5 \%)$ \\
\hline $\begin{array}{l}\text { Departmental } \\
\text { section }\end{array}$ & Angiograpy & $\begin{array}{l}\text { Nuclear } \\
\text { medicine }\end{array}$ & $\begin{array}{l}\text { Radiation } \\
\text { therapy }\end{array}$ & Portable \\
\hline Most frequency & $\begin{array}{c}\text { Malfunctioning } \\
\text { device } \\
7(58.3 \%)\end{array}$ & $\begin{array}{c}\text { Malfunctioning } \\
\text { device } \\
7(56.0 \%)\end{array}$ & $\begin{array}{c}\text { Malfunctioning } \\
\text { device } \\
7(62.2 \%)\end{array}$ & $\begin{array}{c}\text { Procedure-patient } \\
\text { mismatch } \\
4(40.0 \%)\end{array}$ \\
\hline \multirow[t]{2}{*}{ Second frequency } & $\begin{array}{l}\text { Accidental removal of } \\
\text { patient's tubes }\end{array}$ & Patient fall & Wrong procedure & Device damage \\
\hline & $2(16.7 \%)$ & $3(12.0 \%)$ & $5(13.5 \%)$ & $2(20.0 \%)$ \\
\hline \multirow[t]{2}{*}{ Third frequency } & Radiation dose & $\begin{array}{c}\text { Procedure-patient } \\
\text { mismatch }\end{array}$ & Radiation dose & $\begin{array}{l}\text { Accidental removal } \\
\text { of patient's tubes }\end{array}$ \\
\hline & $2(16.7 \%)$ & $2(8.0 \%)$ & $3(8.1 \%)$ & $2(20.0 \%)$ \\
\hline
\end{tabular}

The number outside parentheses is the number of incidents in the departmental section. The number in parentheses is ratio of the contents of incident events in the departmental section.

うに点検によって早期に発見することが大切と考え る. 前期から後期にかけて減少傾向を示したものは, 検査 (治療)の内容に関すること(部位や左右の間違い 等)や患者に関すること(患者誤認や氏名登録間違い 等)であり, 逆に増加傾向を示したものは, 転倒・転落 や点滴ルート等の引き抜け等であった $(\mathrm{Fig} .2(\mathrm{a})(\mathrm{b}))$. 検査 (治療)の内容間違いや患者誤認等は, マニュアル 整備や患者確認ルールの徹底等で発生を抑える可能性 があると考える，一方で，転倒・転落や点滴ルート等 の引き抜けは, 原因要因に注意や確認の不足があり, また，患者の容態にも左右されるため，予測が難しい と思われる。ただし, 安田らは危険予知トレーニング の有用性を述べておりり にために，危険予知トレーニングを積極的に診療現場 に取り入れるべきと考える。

\section{3-2 レベルと経験年数の分析}

レベル別分類について，放射線診療部門と病院全体 を比較すると，放射線診療(技師の業務)でのインシデ ントはレベル $3 a$ と 2 の比率が小さく (Fig. 3), 患者へ の影響度は比較的小さいことが推測される。しかし， レベル $3 \mathrm{a}$ と 2 に分類される患者の転倒転落 (10.9\%)
と患者受傷 (4.5\%) は，放射線診療(技師の業務)のイン シデントレポート全体の 15\%以上を占めるので(Fig. 1)，十分な注意が必要であることに変わりはない。

レポート報告者の経験年数分類について, 放射線診 療部門と病院全体を比較すると, 病院全体では 3 年未 満が $67 \%$ 以上の比率であるのに，放射線診療 (技師の 業務)のインシデントレポートでは, 6 年以上が半数以 上 (55\%) を占め (Fig. 4), 病院全体と異なる傾向を示 した。この要因としては, 病院全体と中央放射線部の 年齢構成が大きく異なり, かつ, 病院全体におけるイ ンシデントの報告者の多くが若年の看護師であること が考えられる。

放射線診療部門におけるインシデントの内容を， 6 年の経験年数を境にして分析すると，6 年未満の経験 年層では，検査(治療)の内容に関すること (18 件/29 件中) と転倒等 (11 件/16 件中) が, 6 年以上の経験年数 のグループよりも多い傾向にあった，検査(治療)の内 容に関すること(部位や左右の間違い，検査の漏れや 順番間違い等)が多い傾向は, 経験年数が少ないこと が間違いや操作ミスにつながっていると推察される. 転倒等に関しても転倒場面に遭遇した経験が，6 年未 満と 6 年以上で異なるために，転倒等の予知能力に差 
があると考えられる、

一方, 6 年以上の経験年層では, 患者に関すること (12 件/15 件中) と点滴ルート等の引抜き (9 件/13 件 中)が, 6 年未満の経験年数のグループよりも多い傾向 にあった。 6 年以上の経験年層で患者に関すること (誤認，氏名登録間違い，フィルム入れ間違い等)が多 い傾向の原因として，臨床経験が長い分逆に慣れによ るマニュアル不励行がある可能性は否定できない. 土 井らは, 経験層 (17 年以上)にとっては, 業務の高度専 門化はエラーの原因になる場合があると報告してお $り^{13)}$, 本分析結果においても 16 年以上の経験層のイ ンシデントレポート (21 件)では, 検査内容に関するこ とが約 33\%を占めていた，33\%を多いとするか少な いとするかは意見が分かれるが, 16 年以上の経験層で

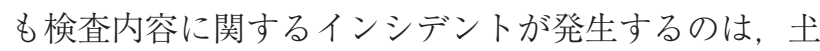
井らの報告の正当性を証明していると考えられる。

\section{3-3 部門別での分析}

\section{3-3-1 撮影部門，透視部門}

撮影部門では，「転倒，転落等」「患者に関すること (患者誤認, 氏名登録間違い等)」「検査内容間違い」が 他の部門より多い傾向にあった (Table)。熊谷らの報 告 ${ }^{5,6)}$ でも, 撮影ミス $(35.8 \%)$, 患者取り違え $(25.5 \%)$, 転倒 (15.8\%)の合計が全体の $77 \%$ を占め, 順位は異な るものの本報告でも同様の結果となった。転倒は, 他 の部門では検査しない「立位」の撮影があるために多 くなる．転倒等は予測不可能な場合があるのも事実だ が，車イスの患者では看護師が付き添う場合も多く, 看護師から事前に患者の状態を十分に聞き取ることが 重要である。撮影部門での転倒, 転落総数 14 件中 7 件が経験年数 4 年未満の技師が当事者であったことか ら, 若い技師が盲目的に撮影オーダ内容を守ろうとし て，立位の指示どおりに無理をして患者を立たせた場 合も考えられる。転倒事故をなくすためにも，立位撮 影時には無理をしないことや，どうしても立位撮影が 必要な場合は必ず介助のスタッフがつくようにするこ とが大切である。

撮影部門では患者(撮影)数が他の部門より圧倒的に 多く，業務にピーク時間帯がある。患者誤認のインシ デントレポートの原因要因の記載には,「多忙であっ た」「待ち患者が多く焦っていた」等の記載が多く，そ の結果, 患者確認作業が流れ作業になり，患者誤認 (Table)の原因になったと考えられる。また，技師一 人の確認(ダブルチェックがない)が普通であり，この ことも原因の一つになるかもしれない. 業務の忙しさ にかかわらず，常に基本に忠実(患者確認手順の遵守)
であることは肝要であり, 2 回の確認(ダブルチェッ ク)の工夫が必要となる。その他, 患者受傷に関して は, 指の挟み込みや装置, カセッテによる擦過傷が撮 影部門では，他の部門と比べて多かった。

透視部門で特徵的なものは「物損」であり (Table), 透視台テーブルのダウン時に椅子等を挟み込むのが顕 著な事例で，当事者は医師であることが多かった。こ のようなインシデントの防止には, 危険エリア(物を 置かないエリア)の徹底と医師への教育が必要となる. また，医師の操作ミスによるインシデントも発生して おり (Table), これらはすべて, 大学病院の特徵であ る若い(経験が少ない)医師が多いことが原因の一つと 推察される。

\section{3-3-2 CT 部門}

CT 部門では, さまざまな輸液ルート等の引抜き事 例が多かった(Table)。これは，ストレッチャーから 検査テーブルへ移動する (または逆) 際に多発してい る。検査台への患者移動は, 技師のみではなく看護師 や医師等との共同作業になるが, 十分な確認と声かけ チーフによる連携が重要である.

CT 部門のインシデントの中に, 頭部検査で, headfirst と設定するべきところを foot-first と入力し, 画 像の左右が反転した事例 (2 件) みられた. 2 件とも当 事者は経験年数 1 年未満の技師であり, 原因は操作上 のケアレスミスだった。画像の左右反転は大きな医療 事故につながる恐れも十分有り, 特に, 救急患者の全 身 CT 検査が増えている現状では見逃せない. 指さ し, 声出し等での確認を徹底させなければならない.

また, 造影開始直後に看護師が誤ってインジェク ターのストップボタンを押した事例もあった。通常, 造影開始から 15 秒程度の間, 看護師は患者の傍で造 影剤の漏れの有無をチェックし，そのときは，いつで も停止できるようにストップボタンの近くに手を添え ている。この事例では，身長の低い看護師が担当しイ ンジェクターのボタンまで手がギリギリの状態で, 誤って(正常のインジェクションなのに) ボタンに触っ たのが原因であった。根本対策として，インジェク ターにリモートタイプ(ケーブルタイプ)のストップボ タンを追加し，身長に関係なく手元で操作できるよう に変更した。インシデントの当事者は看護師である が，技師も含めた関係者全員で情報を共有し対策 (装 置の改良等)を検討する必要があった事例である.

\section{3-3-3 MRI 部門}

MRI 部門におけるインシデントでは, 検査室への金 属等の持込みが特徵的である (Table). 熊谷らの報 告 ${ }^{5,7)}$ でも，物品の飛来 $(26.0 \%)$ が最多の件数である. 
期間で分けると, 前期 (2004 年〜 2008 年)で 7 件, 後期 （2009 年～2013 年)で 8 件発生している (Fig. 2 (a) (b) ). この内容を検討すると, 前期の 7 件中 6 件が患 者により 1 件がスタッフによる持込みで, 後期では 8 件中 2 件が患者で 5 件がスタッフによる持込みであっ た。この傾向の原因は，2008 年度から MRI 部門に看 護師が配属され，全患者の更衣と金属探知機による チェック, 看護師と技師のダブルチェックが実施さ れ, その結果として患者による金属等の持込みが減少 したと考えられる。一方で，依然と職員による金属類 の持込みが発生していて, 職員の持込久事例 6 件中 4 件が患者の容態急变や鎮静処置中の状況で, 当事者は 病棟の看護師や医師であった，患者に容態急変等が発 生した場合, 医療人としては, 無意識の反応で検査室 へ入室してしまうが, 重大な事故(人身事故)の発生に もつながりかねない、緊急時(患者容態の急変など)も 想定し, 関係スタッフ全員の金属物チェックが必要で ある. 土井ら ${ }^{16)}$ や山谷ら ${ }^{17)}$ は, 緊急時や状態の悪化し た患者への対応時に, MRI 部門以外のスタッフによる 金属物の持込みが発生している現状と問題点を報告 し, 安全教育の重要性を指摘している. MRI 検査の安 全性特に強磁場の危険性に関しては，すべての病院ス タッフを対象とした安全教育が必要と考える。

\section{3-3-4 血管造影部門}

血管造影部門では, 2007 年まで過度の患者被ばく線 量の報告があるが，これ以後は線量に関する報告はな い(Fig. 2(a) (b))．２006 年に循環器診療における放射 線被ばくに関するガイドライン ${ }^{18)}$ が発刊され, 術者の 意識変化があったのがその理由の一つとして挙げられ る。また, インジェクターを誤って動かしたために, 接続中のカテーテルが抜去されたり, 動いてしまった というインシデントも発生している(Table). 熊谷ら の報告 ${ }^{5,6)}$ でも, 注入器操作ミ久 $(27.3 \%)$ が血管造影部 門に打けるインシデントの大きな要因となっている. インジェクター操作によるカテーテルの抜去や動き は, 治療成功の可否につながり, また, 医療事故の原 因にもなりかねない危険を含んでいる。インジェク ターの操作には, 指さしや声出し, ダブルチェック等 十分な確認が必要である。

\section{3-3-5 核医学部門}

核医学部門では, 撮影部門に次いで転倒, 転落のイ ンシデントが発生している(Table)。これは, 他部門 に比べて 1 回の検査時間が長いために, 検査テーブル から転落する危険性が大きく, また, 理解度の低い(認 知症など) 患者を対象とする検查が少なくないことが 関係していると考えられる。また，5年前までは，一
人の技師で 2 台の装置を検査(操作)する状況もあり, 患者の観察不足も原因の一つであった。転落は大きな ケガ(医療事故)の可能性が大きいために，患者への十 分な説明, 患者の固定や観察が重要になる.

核医学部門では, Implantable cardioverter defibrillator (ICD) 埋め込み患者の CT 撮影のインシデント や, 造影剂漏れの報告 $(2012,2013$ 年度で 4 件)があ る。これは, Single photon emission computed tomography (SPECT)/CT や PET/CT で吸収補正やフュー ジョンのためにCT 撮影が行われ，更に，核医学検査 終了後に造影 CT 検査が行われる (one stop 検査) ため に，CT 検査に関するインシデントが核医学部門に含 まれるようになったためである。今後は，核医学部門 の技師や看護師の基本スキルに, 造影 $\mathrm{CT}$ 検查を加え ること必要になると考える。

また，医師からの報告なので今回の分析には含まれ ていないが，核医学部門では注射間違い(間違った放 射性医薬品を患者に投与)が 2 件発生している，注射 間違いは, 患者に無用な被ばくを与え, 後日再検査(再 来院)になり，患者クレームの原因になる。また，本院 では，注射薬の調整，投与は医師の業務であるが，注 射間違いはその日の核医学部門の診療全体に影響を与 え, 技師の業務にも関係してくる. 当然, 薬品毎の卜 レーやシリンジへのラベル貼り等の具体策も重要であ るが, 医師以外の職種とのダブルチェックも必要にな ると考える.

\section{3-3-6 放射線治療部門}

5 件の治療内容に関するインシデント (Table)の内 4 件がマーキングに関係していた， 2 件は技師が照射 野中心と CT 中心を誤認した(照射野中心のマーキン グが消えかかる)事例で, 2 件は病棟看護師がマーキン グを修正した事例であった、マーキングは治療に欠か せないので，患者の同意の元で印が消えない工夫が必 要である。

2010 年以降は発生していないが, 2004 2009 年で 過照射や過小照射の 3 件の投与線量間違いが発生して いる(Fig. 2，Table)。幸なことに予定線量と大きな違 いがなかったために，健康被害は発生せず，また，線 量の追加投与で対応できた。 3 件中 2 件はリニアック 装置が故障したため，もう1台のリニアック装置での 治療に切り替えたことが発端となり, 治療計画での誤 入力や未確認が原因となっている. 装置故障等の異常 事態が発生したときには，焦り等によってヒューマン エラーが起きやすいので, ダブルチェックによる確認 が必須になると考える。また，これらのインシデント 発生の後は, 可能な限り治療途中での装置を変更しな 
いように努めている。この線量間違い 3 件全て, 治療 計画での間違いが原因となっている。治療計画では, 計画を作成する医師が確認し，その後技師も確認する ダブルチェックを実施していたが，マンネリ化によっ て機能しなかった。この後では, 治療計画時のミスが 発覚するように，技師による手計算を使った確認も追 加している.

\section{3-3-7 病棟, 手術室撮影}

ポータブル撮影では, フィルムや登録の処理を含め 患者誤認が一番多かった(Table)。原因要因の記載に は「確認不足」「状況の変化」「マニュアル不励行」「焦 り」等があり，技師の年代には特別な傾向はみられな かった。病棟や手術室では環境が変わり，通常の撮影 業務と流れが異なるためにエラーが起きやすいと考え る。また，慣れによるマニュアル飛ばしも一人業務で は起きやすい，ポータブル撮影では，基本に忠実であ ることが一番と考える。

ポータブル装置の誤操作によって, 物損やルート・ チューブの引き抜けも発生している(Table)。狭い病 室での撮影なので，装置を動かす時には細心の注意が 必要となる。また，カセッテによる患者受傷も起こっ ているが，技師だけで無理をせず，病棟看護師に応援 を要請することが患者を守ることにつながる.

\section{3-4 データの共通性}

本報告の分析結果は, 850 床の大学病院のインシデ ントレポートの分析である。従って, すべての病院や 診療所に当てはまる結果ではない，しかし，過去の報 告 ${ }^{5-7.16)}$ やテキスト ${ }^{9)}$ と比較しても極端な相違はない ため，現場の状況の傾向を表していると推察する。10 年前の熊谷らの報告 ${ }^{5-7)}$ と分類項目が異なるために厳 密な比較は難しいが, 報告内容の件数では, 撮影部門 では上位 3 項目(順位は異なる) は同じであり, CT と MRI 部門では最多項目が, 核医学と放射線治療部門で は装置故障を除いた最多項目が同じであった，各部門 の安全に関する特殊性は 10 年前と大きく変わらない ことから，各部門に最適で，より有効な安全対策の必 要性が示唆される。安全対策を再検討し, 今後, より
有効な方法を検討したい.

また，多くの施設でもインシデントレポートの報告 体制があるが，具体的に，どの事象から報告するべき か, 具体的なレベル分類の方法などは, 各施設や安全 管理者の判断で異なっているのが現状である。本結果 では, 装置故障の件数が一番多かったが, 他の施設で は，その判断基準によって異なる可能性がある。今 後, 施設間の比較を可能にするために, 放射線診療分 野だけでも, 報告要件やレベル分類は統一できること を望む。

本報告では, レポート総数が 202 件であるために, 定性的に傾向のみを述べた，総数が少ないために定量 的な解析ができなかった１施設で収集できるレポー 卜数には限りがあるので, 定量的な解析のために, 複 数の施設でのレポート(事例) 収集ができる共同研究が 必要になると考える。また，そのときには前述した報 告要件やレベル分類の統一が必須になると思う。

\section{4. 結 論}

本院で 2004 年〜2014 年に報告のあった放射線診療 に関係するインシデントレポートの中で, 技師が当事 者であった場合や直接的, 間接的に技師が関与した ケース 202 例を分析した。具体的には，インシデント レポートを内容別, レベル別, 経験年数別, 部門別に 分類し, 分析を行った。 その結果, 内容別では, 装置 の故障 (26.2\%), 検査 (治療)の内容に関すること (15.3 $\%)$, 転倒, 転落, しりもち(10.9\%), 患者に関するこ と $(8.4 \%)$, 点滴ルート等の引き抜け等 $(7.9 \%), \mathrm{MRI}$ 検査室への金属類の持込み $(7.4 \%)$ が多かった。 レべ ル別分類ではレベル 1 が, 報告者の経験年数では 6 年 以上 16 年未満が, 一番多かった。部門別では, 撮影, MRI, 放射線治療, 核医学, CT, 血管造影, 透視の順 で多かった。また, 各部門の特徵では, 撮影部門では 転倒, MRI 部門では金属持込み, 放射線治療部門では 装置故障, 核医学部門では転落, CT 部門ではルート 引き抜け，血管造影部門ではインジェクター，透視部 門では物損が注意を要する。 


\section{参考文献}

1) Corrigan JM, Donaldson MS, Kohn LT, et al. To err is human: building a safer health system.Institute of medicine.1999: 1-8.

2）中島和江。序章医療安全への新しいチャレンジ。医療 安全ことはじめ。医学書院，東京，2010: 1-18.

3）専寛子, 上間あおい, 新開裕幸. 1 インシデントレポー 卜再考. 医療安全ことはじめ。医学書院, 東京, 2010: 2134.

4）原田賢治. 教訓を生かして検証していく仕組み作り。医 療安全ことはじめ。医学書院，東京，2010: 164-171.

5）熊谷孝三, 天内 廣，太田原美郎，他，放射線業務におけ る医療事故防止に関する学術調査 第一報ーリスク事例 の調査と分析. 日放技学誌 2004; 60(5): 676-685.

6）熊谷孝三, 天内 廣, 太田原美郎，他. 放射線業務におけ る医療事故防止に関する学術調査第二報一一般撮影, ポータブル撮影, 透視造影検査, 血管造影検査のリスク事 例。日放技学誌 2004; 60(6): 787-795.

7）熊谷孝三, 天内 廣, 太田原美郎，他. 放射線業務におけ る医療事故防止に関する学術調査 第三報 $-\mathrm{CT}$ 検査, MRI 検査, 核医学検査, 放射線治療のリスク事例. 日放 技学誌 2004; 60(7): 927-938.

8) Kruskal JB, Siewert B, Anderson SW, et al. Managing an acute adverse event in a radiology department. Radiographics 2008; 28: $1237-1250$.

9）西村健司，藤本幸宏，加藤京一，他．各論(どのように安 全対策するか)。診療放射線業務の医療安全テキスト。文
光堂, 東京, 2009: 113-249.

10）日本医学放射線学会. 放射線診療事故防止のための指針 Ver.4. http://www.radiology.jp/modules/news/article.php? storyid=75(2014 年 3 月 15 日確認)

11）天内 廣，太田原美郎，山森和美，他．放射線業務の安全 の質管理指針. 日放技学誌 2007; 63(5): 546-556.

12）放射線業務の安全の質管理マニュアル．http://www.jiranet.or.jp/anzenkanri/01_hoshutenken/file/houshasen_kanri manual.pdf (2014 年 3 月 1 日確認)

13）土井司, 河本清澄, 山口和也. 医療安全に対する認識レ ベルと経験年数による差. 日放技学誌 2012; 68(5): 608616.

14）安田光慶, 加藤京一, 内山裕史, 他. 放射線部の医療安全 における危険予知トレーニング (KYT) 導入の効果. 日放 技学誌 2013; 69(7): 788-794.

15）西村健司。有害事象分類に基づいたヒューマンエラーの 防止対策。日放技学誌 2014; 70(1): 57-65.

16）土井司，山谷裕哉，上山 毅，他，MR装置の安全管理 に関する実態調査の報告－思った以上に事故は起こって いるー。日放技学誌 2011; 67(8): 895-904.

17）山谷裕哉，圭井司，上山 毅，他，MR 検査における大 型強磁性体吸引事故の原因分析. 日放技学誌 2013; 69(1): 99-108.

18）循環器診療における放射線被ばくに関するガイドライン. Circulation Journal 2006; 70(4 suppl): 1247-1328. 